LEE, Ching Kwan and Ming SLING, (eds.). 2019. Take Back Our Future: An Eventful Sociology of the Hong Kong Umbrella Movement. Ithaca, NY: Cornell University Press.

Jenny Chan

\title{
OpenEdition
}

Journals

\section{Electronic version}

URL: https://journals.openedition.org/chinaperspectives/11475

DOI: 10.4000/chinaperspectives. 11475

ISSN: 1996-4617

Publisher

Centre d'étude français sur la Chine contemporaine

Printed version

Date of publication: 1 March 2021

Number of pages: 62-63

ISSN: 2070-3449

Electronic reference

Jenny Chan, "LEE, Ching Kwan and Ming SLING, (eds.). 2019. Take Back Our Future: An Eventful

Sociology of the Hong Kong Umbrella Movement. Ithaca, NY: Cornell University Press.", China

Perspectives [Online], 2021/1 | 2021, Online since 01 March 2021, connection on 02 April 2022. URL:

http://journals.openedition.org/chinaperspectives/11475 ; DOI: https://doi.org/10.4000/

chinaperspectives. 11475 
- photographs, development plans and diagrams - that complete the analyses of the projects by providing the reader with essential information on the spatial, environmental, and architectural aspects of the case studies. The series of photographs on Zhengdong by Samuele Pellecchia (pp. 33-57) reveal, in particular, the ambiguous aesthetics of the spaces - a layering of textures, local social practices, and contrasting urban visions.

Although the book includes valuable data on new towns from the point of view of urban development, urbanism, and public policies, its lack of a sociological dimension is regrettable. It seems that its perspective centred on the planning and ongoing construction of new towns supports a bias - that of a state of incompleteness regarding these spaces that are nevertheless already, in reality, the object of practices and appropriations. The top-down planning approach remains highly descriptive, modelled, and flat, disconnected from concrete social processes and from the conflicts and power games that shape the space. A deeper engagement with local realities as a starting point, contextualised by the three case studies, is therefore lacking. Finally, the absence of Chinese transcription in the book proves problematic for a study of "narratives" and "imaginaries."

All that being said, this coherent collaborative work that provides detailed, in-depth, and meticulously illustrated synthetic data represents an undeniable contribution to the literature on new forms of urban life in twenty-first-century China. It is suited to a readership of students and urban design and development specialists, as well as a broader audience of researchers in geography and urban studies.

\section{Judith Audin is a researcher at CEFC and Editor-in-Chief of China} Perspectives. CEFC, Rm. 3029, Academic Building, Hong Kong University of Science and Technology, Clear Water Bay, Kowloon, Hong Kong (jaudin@cefc.com.hk).

\footnotetext{
$T$
}

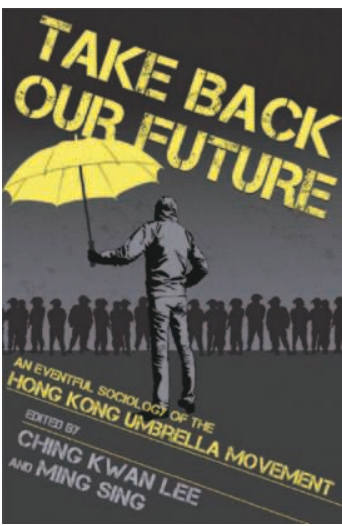

LEE, Ching Kwan and Ming SING, (eds). 2019.

Take Back Our Future: An Eventful

Sociology of the Hong Kong

Umbrella Movement.

Ithaca, NY: Cornell University Press.

\section{JENNY CHAN}

studies, the book's 10 authors look into China's "recolonisation" of Hong

Kong and explain the opportunities that gave rise to the unprecedented protest. To begin with, Ching Kwan Lee draws on William Sewell's formulation of an eventful sociology to comprehend the multiple causes and transformative outcomes of the Umbrella Movement (Chapter 1). At the historic juncture, "events" - defined as a "rare subclass of happenings" - would constitute and empower "new groups of actors," or re-empower "existing groups in new ways" (p. 2). The rupture in contentious politics has awakened tens of thousands of protesters to the popular demand for genuine universal suffrage in electing the Chief Executive of Hong Kong.

In retrospect, Wing Sang Law concurs that the shared "master frame" among Hongkongers was forging a reunion with mainland China with greater democratic representation toward 1997 (Chapter 4). In the aftermath of the 4 June 1989 repression in Beijing, however, "the confidence crisis caused by Hong Kong's uncertain future" was imminent (p. 76). How would "one country, two systems" - the constitutional blueprint established by the 1984 Sino-British Joint Declaration - actually operate? The Basic Law, a mini-constitution that came into force on 1 July 1997 in the Hong Kong Special Administrative Region, is purported to guarantee Hong Kong citizens' rights to freedom and "high degree of autonomy." In practice, as Ming Sing makes clear, Beijing has increasingly tightened control over Hong Kong by restricting electoral competition (Chapter 7). Facing the institutional impasse in law-making and the protracted struggle for democracy, a critical mass of university students and intellectual activists took matters into their own hands when the People's Congress of the People's Republic of China announced a Hong Kong political reform on 31 August 2014.

According to the reform proposal, only two to three candidates (nominated by the Election Committee, which could be easily manipulated by Beijing) would be allowed to run for the 2017 Chief Executive elections. Anger exploded, as clearly manifested by week- 
long class boycotts at universities and secondary schools beginning 22 September. When police fired tear gas at peaceful demonstrators who rallied outside the government headquarters to demand the immediate release of arrested student leaders, the months-long massive opposition was triggered on 28 September.

In a wider socio-cultural context, Alex Chow explains the quest for alternate urban spaces and new economic praxis in and through the Umbrella Movement (Chapter 2). In his capacity as the generalsecretary of the Hong Kong Federation of Student Unions, Chow and fellow student organisers made a powerful critique of capitalist inequality and undemocratic governance in everyday life in Hong Kong. Business elites and power holders, whose privileges were advanced under British colonialism and likewise protected in the 1997 political transition, have continued to monopolise real estate capital, public transportation systems, and infrastructural projects, as well as mass media organisations, thus curbing civil liberties and increasing socioeconomic disparities.

In this digital age, self-mobilised citizens responded to calls for action on Facebook and other social media, rather than to the agitation of trade unions or political parties. Some upheld the principle of nonviolent civil disobedience, while others engaged in militant confrontation, at times provoked by riot police and/or gangs, as vividly demonstrated by Samson Yuen (Chapter 3). In Mongkok, dominated by right-wing "localists" and radical democrats, the socio-political spaces were somewhat exclusionary. By contrast, in Admiralty and Causeway Bay, moderate democrats and progressive leftists co-created a relatively open civic order. Above all, the Umbrella Movement occupiers - making up about 20\% of Hong Kong's 7.2 million residents at the peak of the movement - came from all walks of life (highlighted by Oscar Ho's marvellous photo essay in Chapter 9 and onsite surveys cited in other chapters).

Importantly, Francis Lee adds a caveat that low-cost, easy access to news and information does not necessarily facilitate the social construction of a common identity or the unified adoption of action repertoires (Chapter 5). In Hong Kong, the networked form of protest mobilisations encountered countermobilization orchestrated by the Chinese party-state and its accomplices online and offline and across different sectors. For example, the Hong Kong Confederation of Trade Unions (HKCTU) frequently encountered competition from the proregime Hong Kong Federation of Trade Unions (HKFTU). This weakened union solidarity in support of the unfolding democratic protest.

As Chris Chan narrates, except for the appearance of short-lived unionled actions in late September 2014, a general political strike did not take place (Chapter 6). Amid complaints of "street inconvenience" and "chaos," a taxi union petitioned the government to "reopen the roads" to restore "law and order." This led to an injunction awarded by the courts, with police assisting bailiffs to complete the mission of clearing the streets. In total, the High Court of Hong Kong granted four civil injunctions to various claim-making applicants to eventually evict all three occupied sites. Edmund Cheng cautions that by shifting contention from the arena of politics to the judiciary, a chronic political crisis was merely deferred rather than resolved (Chapter 8).
From a comparative perspective, Jieh-min Wu articulates the "China threats" behind the tactical responses of Taiwan's Sunflower Occupy Movement and Hong Kong's Umbrella Movement (Chapter 10). On 18 March 2014, 200 student activists and social movement leaders occupied the Legislative Yuan (Taiwan's Parliament) for 24 days to call for the retraction of the Cross-Strait Services Trade Agreement. This movement's success has emboldened millennials to advance Taiwanese's interests, while debating issues of sovereignty, statehood, and Taiwanese identity. Interestingly, core activists in Taiwan and Hong Kong who reached out to learn from each other were also communicating with civil society groups all over the world.

The spheres of democracy and livelihood are closely intertwined, not separate entities. How do we take back our future? With the passage of the National Security Law on 30 June 2020, prodemocracy political parties and activists similarly face greater struggles for survival in Hong Kong. The authoritarian Chinese state (Ming Sing puts it more directly as "the largest dictatorial regime on earth," p. 241) has intensified surveillance over educators, journalists, and social commentators. But we should not give up. This significant collection of well-researched essays with its reflections on the past and present will help readers strategize to create our future.

I Jenny Chan is Assistant Professor of sociology at the Hong Kong Polytechnic University. HJ433, Department of Applied Social Sciences, the Hong Kong Polytechnic University (jenny.wl.chan@polyu.edu.hk). 